\title{
PROFIL PENGGUNAAN OBAT ANTIDIABETIK ORAL PADA PASIEN RAWAT JALAN PENDERITA DIABETES MELLITUS TIPE II
}

\author{
Ine Suharyani*,Nisya Chairunisya**Aida Maftuhah***
}

\begin{abstract}
ABSTRAK
Peningkatan kasus serta tingkat kematian pada pasien Diabetes Mellitus disebabkan oleh perkembangan teknologi yang mempengaruhi pola hidup masyarakat. Pola hidup ini dapat memberikan dampak negatif berupa meningkatnya prevalensi berbagai penyakit degeneratif salah satunya Diabetes Mellitus. Diabetes Mellitus Tipe II merupakan salah satu penyakit dengan angka kejadian yang cukup tinggi di RSUD 45 Kuningan. Penelitian ini merupakan penelitian deskriptif, data diambil dengan metode retrospektif dengan melihat rekam medis pasien rawat jalan yang berobat pada periode bulan Juli-Desember 2013 di RSUD 45 Kuningan. Sampel yang diambil menggunakan metode random sebanyak 60 sampel dari 130 pasien rawat jalan penderita Diabetes Mellitus Tipe II di RSUD 45 Kuningan. Hasil penelitian menunjukkan bahwa dari 60 pasien, $45 \%$ menggunakan obat antidiabetik oral tunggal yaitu metformin dan sisanya merupakan kombinasi dengan obat lain. Penggunaan kombinasi yang paling banyak adalah metformin+glikuidon sebanyak $15 \%$. Berdasarkan jenis kelamin, penderita Diabetes Mellitus Tipe II didominasi oleh perempuan sebanyak 53\%,sedangkan berdasarkan usia paling banyak 46-65 tahun sebanyak $82 \%$. Berdasarkan kadar gula darah sewaktu, penderita Diabetes Mellitus Tipe II yang paling banyak dengan nilai $\geq 200 \mathrm{mg} / \mathrm{dl}$ adalah $65 \%$. Penyakit penyerta yang menyertai Diabetes Mellitus Tipe II yang paling banyak adalah penyakit dispepsia sebanyak $13,33 \%$, hipertensi $10 \%$, dan rheumatoid arthtritis $6,66 \%$. Obat penyerta yang paling banyak diberikan kepada pasien Diabetes Mellitus yaitu Amlodipin/Amdixal sebanyak 43\%.
\end{abstract}

Kata Kunci : Diabetes Mellitus, antidiabetik oral.

\section{ABSTRACT}

The increased of case and mortality of Mellitus Diabetes patient because of the growth of technology expanding very fast recently, can influence pattern live society. Pattern live this also can give negative impact to increase of various degenerativedisease like MellitusDiabetes. Mellitus Diabetes Type II represent as one of the disease which high amount case in RSUD 45 Kuningan. This research represent descriptive research, data taken with retrosfectivemethod and studying medical record of some patient which medicinize at period of July until December 2013. Sampel taken use method of random counted 60 sample from 130 outpatient patient of Diabetes Mellitus Type of II.Result of this research showd that from 60 patient, $45 \%$ usedsingle oral antidiabeticwas metformin. Usage of combination which at most is metformin+glikuidon counted $15 \%$. According to the gender, patient of Diabetes Mellitus Type of II predominated by woman was 53\%. While to age faction that is among/between 46-65 year counted $82 \%$. Azzording to blood sugar concentrated, patient of Mellitus Diabetes Type of II which at most with value $\geq 200 \mathrm{mg} / \mathrm{dl}$ counted $65 \%$. Disease in combination with Diabetes Mellitus Type II aredyspepsia counted 13,33\%, hypertension 10\%, and rheumatoid arthtritis $6,66 \%$. The most drug incombination was Amlodipin / Amdixal counted 43\%.

Keywords : Diabetes Mellitus, oral antidiabetik drug.

\footnotetext{
* Staf Pengajar Akademi Farmasi Muhammadiyah Kuningan

** Staf Pengajar Akademi Farmasi Muhammadiyah Kuningan

***Alumni Akademi Farmasi Muhammadiyah Kuningan Tahun 2014
} 


\section{PENDAHULUAN}

Perkembangan teknologi yang berkembang sangat pesat akhir-akhir ini mempengaruhi pola hidup masyarakat dan memberikandampak negatif berupa meningkatnya prevalensi berbagai penyakit degeneratif salahsatunya Diabetes Melitus (DM). ${ }^{1}$

Diabetes Mellitus (DM) merupakan suatu penyakit dengan gangguan metabolisme karbohidrat, lemakdan protein. Hal ini disebabkan oleh kecukupan kadar hormon insulin. Insulin itu sendiri merupakan salah satu hormon yang mengatur kadar glukosa dalam darah. ${ }^{1}$ Diabetes melitus merupakan penyakit yang paling banyak menyebabkan terjadinya penyakit lain (komplikasi). Penyakit ini berkaitan dengan peningkatan kadar glukosa darah (hiperglikemia) diatas 126mg/dl dalam keadaan puasa dan diatas $200 \mathrm{mg} / \mathrm{dl}$ pada 2 jam setelah makan, disertai keluhan poliuri (sering buang air kecil), polidipsi (meningkat rasa haus), dan polifagi (rasa lapar berlebihan) serta penurunan berat badan. Kenaikan kadar glukosa dalam darah dalam keadaan puasa maupun 2 jam setelah makan disebabkan penurunan sekresi insulin yang progresif dilatarbelakangi oleh resistensi insulin. Berbagai penelitian menunjukkan bahwa dengan melakukan pengendalian kadar glukosa darah yang baik maka komplikasi mikroangiopati dan makroangiopati dapat dikurangi. ${ }^{2}$

Berdasarkan latar belakang tersebut, maka kami melakukan penelitianmengenai profil penggunaan obat antidiabetika oral pada pasien rawat jalan di Rumah Sakit Umum Daerah (RSUD)'45 Kuningan. Melalui penelitian ini diharapkan akan diperoleh gambaran berbagai obat antidiabetika oral yang digunakan dalam penanganan diabetes mellitus tipe II serta penggunaan obat-obat untuk penyakit penyertanya.

\section{METODE PENELITIAN}

Penelitian ini merupakan penelitian deskriptif, data diambil dengan metode retrospektif dan dengan melihat rekam medis pasien yang berobat pada periode Juli sampai denganDesember 2013 di RSUD 45 Kuningan. Pengumpulan data dilakukan dengan penelusuran rekam medik pasien diabetes melitus tipe 2 di RSUD 45 Kuningan. Data yang diambil dari rekam medik meliputi data pasien, profil demografi, obat antidiabetik yang digunakan dan data klinis hasil pemeriksaan laboratorium yang tercantum pada rekam medik. Sampel yang diambil hanya 60 orang pasien penderita Diabetes Mellitus rawat jalan di RSUD 45 Kuningan periode Juli-Desember 2013. Kriterian inklusi sampel adalah pasien umum bukan pasien askes di poliklinik rawat jalan RSUD'45 Kuningan yang berobat pada periode Juli - Desember 2013, dengan diagnosis Diabetes Melitus tipe II yang mendapatkan obat antidiabetik oral. Rekam medis yang dipilih adalah rekam medis yang memiliki catatan lengkap meliputi identitas pasien, obat antidiabetik yang digunakan untuk pengobatan dan data klinis kadar gula darah sewaktu.

\section{HASIL DAN PEMBAHASAN \\ Data Demografi Pasien Jenis Kelamin}

Tabel 1 Persentase Pasien Diabetes Mellitus Tipe 2 Berdasarkan Jenis Kelamin

\begin{tabular}{cccc}
\hline No. & Jenis Kelamin & Jumlah Pasien & Persentase (\%) \\
\hline 1 & Perempuan & 32 & $53 \%$ \\
2 & Laki-laki & 28 & $47 \%$ \\
\hline & Jumlah Total & 60 & $100 \%$ \\
\hline
\end{tabular}

Berdasarkan jenis kelamin, data yang didapat dari Rekam Medik RSUD 45 Kuningan selama periode Juli - Desember 2013, pasien yang menderita Diabetes Mellitus Tipe II lebih banyak terjadi pada perempuan dengan jumlah 32 pasien (53\%) dan laki-laki sebanyak 28 pasien (47\%). 
Tabel 2 Persentase Pasien Diabetes Mellitus Tipe II Berdasarkan Usia

\begin{tabular}{cccc}
\hline No. & Usia (Tahun) & Jumlah Pasien & Persentase (\%) \\
\hline 1 & $\leq 12-25$ (Remaja) & Tidak ada & Tidak ada \\
2 & $26-45$ (Dewasa) & 5 & $8 \%$ \\
3 & $46-65$ (Lansia) & 49 & $82 \%$ \\
4 & $\geq 65$ (Manula) & 6 & $10 \%$ \\
\hline & Jumlah Total & 60 & $100 \%$ \\
\hline
\end{tabular}

Berdasarkan golongan usia penderita Diabetes Mellitus Tipe II dari data yang diperoleh selama periode Juli - Desmber 2013, Diabetes Mellitus Tipe II sering terjadi pada orang dewasa terutama usia > 40 tahun. Golongan usia yang paling banyak menderita menderita penyakit DM Tipe II pada pasien rawat jalan di RSUD 45 Kuningan adalah usia antara 46 - 65 tahun yaitu sebanyak 49 pasien dengan persentase 82

\section{Data Kadar Gula Darah}

Kadar gula darah sewaktu merupakan hasil pemeriksaan sesaat pada suatu hari tanpa memperhatikan waktu makan terakhir. Hasil pemeriksaan gula darah sewaktu dibagi menjadi 3, yaitu : ${ }^{3}$

1. Normal : $\leq 140 \mathrm{mg} / \mathrm{dl}$

2. Toleransi glukosa terganggu :141 $-200 \mathrm{mg} / \mathrm{dl}$

3. Diabetes : $\geq 200 \mathrm{mg} / \mathrm{dl}$

Tabel 3 Persentase Kadar Gula Darah Sewaktu Pada Pasien Diabetes Melitus Tipe II

\begin{tabular}{cccc}
\hline No. & Nilai & Jumlah Pasien & Persentase (\%) \\
\hline 1 & $\leq 140 \mathrm{mg} / \mathrm{dl}$ & 10 & $17 \%$ \\
2 & $141-200 \mathrm{mg} / \mathrm{dl}$ & 11 & $18 \%$ \\
3 & $\geq 200 \mathrm{mg} / \mathrm{dl}$ & 39 & $65 \%$ \\
\hline & Jumlah Total & 60 & $100 \%$
\end{tabular}

Berdasarkan data dari tabel 3 diatas didapat nilai kadar Gula Darah Sewaktu (GDS) pada pasien DM Tipe II yang dilihat dari data rekam medik di RSUD 45 Kuningan sebanyak 60 pasien. Pasien paling banyak mempunyai nilai GDS $\geq 200 \mathrm{mg} / \mathrm{dl}$ yang sudah termasuk Diabetes Mellitus sebanyak $39(65 \%)$.

\section{Penggunaan Obat Antidiabetik Yang Diberikan Pada Pasien DM Tipe II}

obat antidiabetik yang sering digunakan pada pasien Diabetes Mellitus Tipe II serta kombinasi obat antidiabetik yang diberikan dapat dilihat pada tabel dibawah ini :

Tabel 4 Persentase Penggunaan Obat Antidiabetik Tunggal dan Kombinasi yang digunakan pada pasien Diabetes Mellitus Tipe II

\begin{tabular}{cccc}
\hline No. & Nama Obat & Jumlah Pasien & Persentase (\%) \\
\hline 1 & Metformin & 27 & $45 \%$ \\
2 & Glikuidon & 13 & $22 \%$ \\
3 & Glimepirid & 5 & $8 \%$ \\
4 & Glibenklamid & 2 & $3 \%$ \\
5 & Metformin + Glikuidon & 9 & $15 \%$ \\
6 & Metformin + Glimepirid & 3 & $5 \%$ \\
7 & Metformin + Glibenklamid & 1 & $2 \%$ \\
\hline
\end{tabular}


Berdasarkan jenis obat antidiabetik yang digunakan dalam pengobatan pada pasien Diabetes Mellitus Tipe II secara oral, obat antidiabetik yang paling banyak digunakan adalah metformin yaitu sebanyak 27 pasien dengan persentase mencapai 45\%. Obat antidiabetik lainnya yang diberikan pada pasien Diabetes Mellitus Tipe II adalah glikuidon sebanyak 13 pasien dengan persentase mencapai $22 \%$, glimepirid sebanyak 5 pasien dengan persentase $8 \%$, sedangkan glibenklamid hanya diberikan pada 2 orang pasien pasien Diabetes Mellitus Tipe II dengan persentase 3\%.

\section{Pasien Dengan Penyakit Penyerta DM Tipe II}

Tabel 4. Persentase Pasien Dengan Penyakit Penyerta Diabetes Mellitus TipeII

\begin{tabular}{cccc}
\hline No & Penyakit Penyerta & $\begin{array}{c}\text { Jumlah } \\
\text { Pasien }\end{array}$ & $\begin{array}{c}\text { Persentase } \\
(\%)\end{array}$ \\
\hline 1 & DM+DSP & 8 & $13,33 \%$ \\
2 & DM+HPN & 6 & $10 \%$ \\
3 & DM+RA & 4 & $6,66 \%$ \\
4 & DM+HLD & 1 & $1,66 \%$ \\
5 & DM+GRN & 1 & $1,66 \%$ \\
6 & DM+RA+DSP & 8 & $13.33 \%$ \\
7 & DM+HPN+DSP & 6 & $10 \%$ \\
8 & DM+HPN+RA & 4 & $6,66 \%$ \\
9 & DM+HPN+GRN & 1 & $1,66 \%$ \\
10 & DM+HPN+SYR & 1 & $1,66 \%$ \\
11 & DM+HPN+HLD & 1 & $1,66 \%$ \\
12 & DM+HPN+HPR & 1 & $1,66 \%$ \\
13 & DM+HLD+DSP & 1 & $1,66 \%$ \\
14 & DM+HPR+DSP & 1 & $1.66 \%$ \\
15 & DM+GRN+SYR & 1 & $1,66 \%$ \\
16 & DM+HPN+DSP+RA & 6 & $10 \%$ \\
17 & DM+HPN+KRD+RA & 1 & $1,66 \%$ \\
18 & DM+HPN+HLD+RA & 1 & $1,66 \%$ \\
19 & DM+HPN+HPR+DSP & 1 & $1,66 \%$ \\
20 & DM+HPR+RA+DSP & 1 & $1,66 \%$ \\
21 & DM+HLD+RA+DSP & 1 & $1,66 \%$ \\
22 & DM+HLD+HPN+DSP+RA & 2 & $3,33 \%$ \\
22 & DM+HLD+HPN+DSP+SYR & 1 & $1,66 \%$ \\
23 & DM+HPN+KRD+DSP+HLD & 1 & $1,66 \%$ \\
\hline & Jumlah Total & $\mathbf{6 0}$ & $\mathbf{1 0 0 \%}$ \\
\hline
\end{tabular}

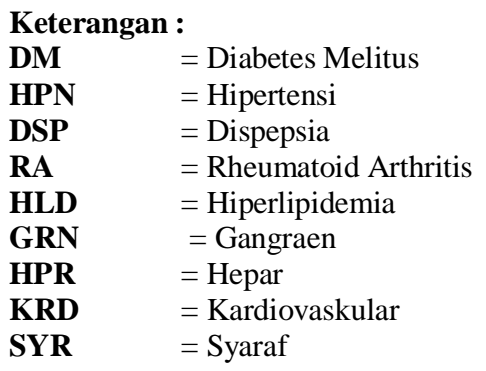

Setelah dianalisis ternyata banyak penyakit penyerta Diabetes Mellitus Tipe II. Dari tabel 4 diatas penyakit penyerta DM Tipe II persentase paling tinggi, terdapat pada pasien yang memiliki 1 penyakit penyerta DM Tipe II adalah penyakit Dispepsia sebanyak 8 pasien dengan persentase 13,33\%, dan penyakit Hipertensi sebanyak 6 pasien dengan persentase $10 \%$. Penyakit lainnya yaitu pasien yang memiliki 2 penyakit penyerta DM Tipe II adalah penyakit Rheumatoid Arthtritis sebanyak 8 pasien dengan persentase $13,33 \%$. 


\section{Penggunaan Obat Penyerta DM Tipe II}

Dari analisis data penggunaan obat penyakit penyerta DM Tipe II ada 25 jenis obat yang diberikan kepada pasien DM, obat-obat tersebut adalah sebagai berikut :

Tabel 5 : Persentase Penggunaan Obat Penyerta DM Tipe II

\begin{tabular}{|c|c|c|c|}
\hline No & Obat Penyerta & $\begin{array}{c}\text { Jumlah } \\
\text { Pasien }\end{array}$ & Persentase (\%) \\
\hline 1 & Omeprazole & 17 & $28 \%$ \\
\hline 2 & Lansoprazole & 5 & $8 \%$ \\
\hline 3 & Ranitidin & 14 & $23 \%$ \\
\hline 4 & Sucralfat sirup & 7 & $12 \%$ \\
\hline 5 & Dexanta sirup & 1 & $2 \%$ \\
\hline 6 & Amlodipin/Amdixal & 26 & $43 \%$ \\
\hline 7 & Candesartan/Canderin & 3 & $5 \%$ \\
\hline 8 & Captopril & 2 & $3 \%$ \\
\hline 9 & Aspilet & 7 & $12 \%$ \\
\hline 10 & $\begin{array}{c}\text { Neurodex/Neurosanbe/Sohobion/Grahabi } \\
\text { on }\end{array}$ & 19 & $32 \%$ \\
\hline 11 & Nat.Diklofenak & 2 & $3 \%$ \\
\hline 12 & B-Complex & 4 & $7 \%$ \\
\hline 13 & Meloxicam & 4 & $7 \%$ \\
\hline 14 & Methylprednisolon & 1 & $2 \%$ \\
\hline 15 & Allupurinol & 1 & $2 \%$ \\
\hline 16 & Simvastatin/Atorvastatin & 8 & $13 \%$ \\
\hline 17 & Clopidogrel & 1 & $2 \%$ \\
\hline 18 & Spironolacton/letonal & 5 & $8 \%$ \\
\hline 19 & Micardis & 1 & $2 \%$ \\
\hline 20 & Sohobal & 2 & $3 \%$ \\
\hline 21 & Folaplus & 1 & $2 \%$ \\
\hline 22 & Vastigo & 1 & $2 \%$ \\
\hline 23 & Curcuma & 2 & $3 \%$ \\
\hline 24 & Proliva & 2 & $3 \%$ \\
\hline 25 & $\mathrm{NS} / \mathrm{NaCl}$ & 3 & $5 \%$ \\
\hline
\end{tabular}

Dapat dilihat dari hasil tabel diatas bahwa penggunaan obat penyerta DM Tipe II yang paling banyak adalah obat Amlodipin/Amdixal dengan jumlah 26 pasien dengan persentase 43\%, karena penderita diabetes tipe II pada umumnya memiliki kondisi yang disebut dengan resistensi insulin. Resistensi insulin adalah kondisi dimana seseorang memiliki jumlah insulin yang cukup untuk merombak glukosa, namun tidak bekerja sebagaimana mestinya. Insulin yang ada tidak digunakan untuk merombak glukosa, yang mengakibatkan kadar glukosa dalam darah naik, yang mengakibatkan diabetes. Insulin yang tidak bekerja ini tidak akan dirombak menjadi apapun, dia akan tetap berada dalam bentuk insulin. Insulin berlebih ini lah yang menyebabkan terjadinya hipertensi pada pasien diabetes. ${ }^{5}$ 


\section{PEMBAHASAN}

\section{Jenis Kelamin}

Pasien yang menderita Diabetes Mellitus Tipe II lebih banyak terjadi pada perempuan dengan jumlah 32 pasien (53\%) dan laki-laki sebanyak 28 pasien $(47 \%)$. Menurut penelitian perempuan lebih banyak menderita Diabetes Mellitus Tipe II dibandingkan dengan laki-laki karena tingginya prevalensi obesitas pada perempuan, DM pada kehamilan dan pada premenopouse juga menjadi faktor timbulnya DM Tipe II sehingga pasien yang menjalani pengobatan rawat jalan di RSUD 45 Kuningan lebih banyak perempuan. ${ }^{4}$

\section{Umur}

Golongan usia yang paling banyak menderita menderita penyakit DM Tipe II pada pasien rawat jalan di RSUD 45 Kuningan adalah usia antara 46 - 65 tahun yaitu sebanyak 49 pasien dengan persentase $82 \%$, karena golongan usia tersebut daya tahan tubuhnya menurun dan organ tubuhnya kurang berfungsi lagi dengan baik, pola hidup seperti makan dan olahraga kurang diperhatikan sehingga rentan terhadap penyakit tersebut. ${ }^{4}$ Kedua, pada golongan usia $\geq 65$ tahun sebanyak 6 pasien dengan persentase $10 \%$. Ketiga, pada golongan usia $26-45$ tahun sebanyak 5 pasien dengan persentase $8 \%$. Sementara itu, pada golongan usia antara $\leq 12-25$ tahun tidak terdapat pasien Diabetes Mellitus Tipe II pada sampel yang dianalisis sebanyak 60 sampel. Resiko Diabetes Mellitus Tipe II akan meningkat dengan bertambahnya usia dan manusia akan mengalami penurunan fisiologis yang akan berakibat menurunnya fungsi endokrin pankreas untuk memproduksi insulin. ${ }^{4}$

\section{Penggunaan Obat Antidiabetik Yang Diberikan Pada Pasien DM Tipe II}

Pemberian kombinasi obat antidiabetik dalam terapi Diabetes Mellitus Tipe II yang paling banyak yaitu kombinasi metformin + glikuidon sebanyak 9 pasien dengan persentase $15 \%$, kedua kombinasi metformin+glimepirid sebanyak 3 pasien dengan persentase 5\%, sedangkan kombinasi metformin+glibenklamid hanya 1 pasien dengan persentase $2 \%$. Kombinasi antara golongan sulfonilurea dengan metformin saat ini merupakan kombinasi yang rasional karena mempunyai cara kerja yang sinergis sehingga kombinasi ini dapat menurunkan glukosa darah lebih baik dari pada pengobatan tunggal. ${ }^{4}$

\section{Pasien Dengan Penyakit Penyerta DM Tipe II}

Diabetes yang tidak terkontrol dengan baik dapat menimbulkan komplikasi akut dan kronis. Komplikasi akut terjadi jika kadar glukosa darah seseorang meningkat ataupun menurun tajam dalam waktu relatif singkat. Komplikasi kronis berupa kelainan pembuluh darah yang akhirnya bisa menyebabkan serangan jantung, syaraf dan penyakit dalam lainnya. ${ }^{4}$

\section{Penggunaan Obat Penyerta DM Tipe II}

Hasil penelitian menunjukkan bahwa penggunaan obat penyerta DM Tipe II yang paling banyak adalah obat Amlodipin/Amdixal dengan jumlah 26 pasien dengan persentase 43\%, karena penderita diabetes tipe II pada umumnya memiliki kondisi yang disebut dengan resistensi insulin. Resistensi insulin adalah kondisi dimana seseorang memiliki jumlah insulin yang cukup untuk merombak glukosa, namun tidak bekerja sebagaimana mestinya. Insulin yang ada tidak digunakan untuk merombak glukosa, yang mengakibatkan kadar glukosa dalam darah naik, yang mengakibatkan diabetes. Insulin yang tidak bekerja ini tidak akan dirombak menjadi apapun, dia akan tetap berada dalam bentuk insulin. Insulin berlebih ini lah yang menyebabkan terjadinya hipertensi pada pasien diabetes. ${ }^{5}$

\section{KESIMPULAN}

1. Dari 60 pasien Diabetes Mellitus Tipe II di RSUD 45 Kuningan, pasien Diabetes Mellitus didominasi oleh : 
1) Perempuan $53 \%$

2) Laki-laki $47 \%$

3) Golongan usia yang paling banyak terdiagnosa Diabetes Mellitus Tipe II yaitu usia 46 - 65 tahun sebanyak $82 \%$, sedangkan golongan usia yang paling sedikit yaitu $26-45$ tahun sebanyak $8 \%$.

4) Berdasarkan data pemeriksaan kadar gula darah sewaktu, pasien yang gula darahnya normal hanya $17 \%$, diatas normal/toleransi gula terganggu sebanyak $18 \%$, dan pasien yanggula darahnya tinggi sebanyak $65 \%$.

5) Berdasarkan data obat antidiabetik yang digunakan pada pasien Diabetes Mellitus di RSUD 45 Kuningan, obat antidiabetik tunggal yang paling banyak digunakan adalah Metformin sebanyak 27 pasien $65 \%$, sedangkan obat kombinasi pada golongan antidiabetiknya yang banyak digunakan adalah Metformin + Glikuidon sebanyak 9 pasien $15 \%$.

6) Penyakit penyerta yang menyertai pasien Diabetes Mellitus Tipe II di RSUD 45 Kuningan periode Juli-Desember 2013 yang paling banyak adalah penyakit Dispepsia 13,33\%, Hipertensi10\% dan Rheumatoid Arthtritis 6,66\%.

7) Penggunaan obat penyakit penyerta pasien Diabetes Mellitus Tipe II di RSUD 45 Kuningan periode Juli-Desember 2013 yang paling banyak digunakan adalah Amlodipin/Amdixal dengan jumlah 26 pasien $43 \%$.

\section{SARAN}

1. Perawat

Memberikan penyuluhan secara rutin tentang upaya menstabilkan gula darah dan selalu mengontrol gula darah

2. Instalasi farmasi

Meningkatkan pelayanan dan peneyediaan secara berkenambungan untuk obat-obat yang paling banyak di konsumsi pasien

3. Pasien

Sebaiknya selalu melakukan pengecekan gula darah secara teratur dan konsumsi makanan diet diabetes sehingga dapat mengontrol gula darah

\section{DAFTAR PUSTAKA}

1. Anonim. Memahami Gula Darah. [Diakses tanggal 02 April 2014]. Diunduh dari http://healdiabetesi.wordpress.com

2. Depkes RI. Pharmaceutical Care Untuk Penyakit Diabetes Mellitus.Jakarta:Direktorat Bina Farmasi Komunitas Klinik;2005

3. Sudoyo, W Aru, dkk. Buku Ajar Ilmu Penyakit Dalam. Jakarta:FK UI;2009

4. Wells,B.G.J.T. Dipiro,T.L. Sinwing hammer, and C.V Dipiro, Pharmacotherapy Handbook, $7^{\text {th }}$ ed, The Mc.Graw Hill. Compnies.,Inc.United States; 2009

5. Anonim. Gula darah sewaktu. [Diakses tanggal 27 Mei 2014]. Diunduh dari www.guladarah.com 